\title{
Correlation of Physical Fitness Levels with Body Mass Index (BMI) in Medical Students
}

\author{
Fatima Durain, Ailani Vinita, Singhal Usha, Dadheech Gora, Aren Sunil
}

\begin{abstract}
Background: The aim of present study to find out physical fitness levels in male and female medical students and these levels were correlated with BMI. The study was conducted amongst 104 healthy medical student's age 17-29 years (51 males and 53 females) selected from NIMS medical college jaipur. Subjects suffering from any chronic disease or subjects addicted to tobacco, alcohol and drugs were excluded from study.

Material and methods: A structured proforma was given to subjects to elicit lifestyle and systemic diseases. Parameters like $B P$, pulse rate, respiratory rate and temperature were also recorded. The physical fitness was assessed by measuring height and weight and BMI was calculated by using Quetelets body mass index formula $\left(B M I=\right.$ Weight $($ Kg. $) /$ height ${ }^{2}$ (meter). Waist and hip ratio was also observed. Similarly estimation of aerobic capacity ( $\mathrm{VO}_{2}$ max) of subjects was done as classification given by (1).

Result: The result of this study suggest that physical fitness performance was better in male subjects but the aerobic capacity of female subjects was higher than males and they have normal BMI as compared to males. It was also observed that obesity has adverse impact on physical activity.

Conclusion: The female subjects have lower level of physical fitness as compare to males but the aerobic capacity was found to be higher in females than males and obesity has an adverse impact on physical activity.
\end{abstract}

Keywords: physical fitness, body mass index, waist hip ratio, aerobic capacity.

\section{Introduction}

Physical fitness comprises a set of outcome or traits that relates to ability to perform physical activity (2). Fitness in general has five components: - aerobic capacity, muscle power and strength, muscular indurance, flexibility and body composition. So nowadays physical fitness is considered as production of morbidity and mortality for cardiovascular disease $(3,4,5)$. Obesity is characterized by increased mass of adipose tissue that results from systemic imbalance between food intake and energy expenditure (6). Obesity is also being recognised as public health epidemic and modifiable risk factor for coronary heart diseases $(7,8)$. The magnetic impact of obesity on health includes an increase risk of several chronic diseases such as type II diabetes (9), hypertension (10), and dyslipidemia (11) CVS diseases (12). Obesity is also associated with increase total mortality (13). Altered respiratory functions due to obesity may lead to sleep apnoea and respiratory failure (14).

The present study emphasis on:-Physical fitness of medical students The need for students to measure and analyse their physical fitness for their own benefit To correlate between physical fitness and BMI

\section{Material And Method}

The present study was conducted on medical students in Department of Physiology, NIMS Medical College Jaipur. Subjects consisted of 104 medical students from NIMS medical college jaipur.51 male and 53 female students between age group of 17-29 years. Subjects suffering from any chronic disease or addiction were excluded from study. A Performa was given to subjects to elicit the details of life style and systemic disease. Height and weight of each subject was recorded and various vital parameters like blood pressure, pulse rate, respiratory rate, and temperature were recorded. A detailed physical examination was done with the consent of the subjects. The physical fitness was assessed by measuring height (Holtain stadiometer) and weight (digital balance scale) and BMI (Body mass index was calculated by using Quetelets formula) BMI= weight $(\mathrm{kg}) /$ height $^{2}(\mathrm{~m})$. Based on this the subjects were classified as International classification of BMI given by WHO. The International classification of adult overweight, underweight and obesity is according to BMI $(15,16,17)$. Waist-hip ratio was determined as fat store around waist poses a great risk to health than fat stored anywhere else in body (WWW. Women -health info.com). Aerobic capacity $\left(\mathrm{VO}_{2}\right.$ max) of subjects was estimated by using following formula.

$\mathrm{VO}_{2} \max (\mathrm{L} / \mathrm{min})=0.023 \times$ body weight $(\mathrm{Kg})-0.034 \times$ age $($ years $)+1.652$

$\mathrm{VO}_{2} \max (\mathrm{ml} / \mathrm{Kg} \cdot \min )=\mathrm{VO}_{2} \max (\mathrm{L} / \mathrm{min}) /$ body weight $\times 1000$

Aerobic capacities were calculated and subjects were classified accordingly in various fitness grades (1). The subjects also performed push up test (18) and sit and reach test (19) to determine their general physical fitness. The statistical analysis was done and results were presented as mean and SD independent ' $t$ ' test to assess overall difference between male and female in relation to height, weight and BMI. P value less than or equal to 0.05 on two side test were considered statistically significant.

\section{Observation Tables}

Table 1: Distribution of Weight $(\mathrm{Kg})$ in male and female subjects

All values are Mean \pm SD

\begin{tabular}{|c|c|c|}
\hline Sex & $\mathrm{n}$ & Mean \pm SD \\
\hline Male & 51 & $70.52 \pm 13.54$ \\
\hline Female & 53 & $55.03 \pm 8.18$ \\
\hline
\end{tabular}

$\mathrm{P}<0.5$

Table 2: Distribution of Height $(\mathrm{cm})$ in male and female subjects

\begin{tabular}{|l|r|c|}
\hline Sex & $\mathrm{n}$ & Mean \pm SD \\
\hline Male & 51 & $166 \pm 9.95$ \\
\hline Female & 53 & $152 \pm 16.2$ \\
\hline
\end{tabular}


All values are mean $\pm \mathrm{SD}$

$\mathrm{P}<0.5$

Table 3: Distribution of BMI $\left(\mathrm{Kg} / \mathrm{m}^{2}\right)$ in male and female subjects

All values are mean $\pm \mathrm{SD}$

\begin{tabular}{|l|c|c|}
\hline Sex & $\mathrm{n}$ & Mean \pm SD \\
\hline Male & 51 & $25.15 \pm 5.34$ \\
\hline Female & 53 & $22.15 \pm 4.13$ \\
\hline
\end{tabular}

$\mathrm{P}<0.05$

Table 4: Number of male / female subjects in different grades of BMI $\left(\mathrm{Kg} / \mathrm{m}^{2}\right)$

\begin{tabular}{|c|c|c|c|c|}
\hline Grade of BMI & $\begin{array}{c}\text { Male } \\
\mathrm{n}=51\end{array}$ & $\%$ & $\begin{array}{c}\text { Female } \\
\mathrm{n}=53\end{array}$ & $\%$ \\
\hline Normal & 28 & 54.9 & 39 & 73.6 \\
\hline Underweight & 2 & 3.9 & 4 & 7.5 \\
\hline Overweight & 10 & 19.6 & 5 & 9.4 \\
\hline Obese & 11 & 21.6 & 5 & 9.4 \\
\hline
\end{tabular}

Table 5: Mean \pm SD of Waist Hip ratio in male and female subjects

All values are mean $\pm \mathrm{SD}$

\begin{tabular}{|c|c|c|}
\hline Sex & n & Mean \pm SD \\
\hline Male & 51 & $0.82 \pm 0.10$ \\
\hline Female & 53 & $0.75 \pm 0.05$ \\
\hline
\end{tabular}

$\mathrm{P}<0.5$

Table 6: Different risk group of Waist - Hip ratio in subjects

\begin{tabular}{|c|c|c|c|}
\hline Risk Groups & Male $\mathrm{n}=51$ & Female $\mathrm{n}=53$ & Total $\mathrm{n}=104$ \\
\hline Low & $46(90.1 \%)$ & $53(100 \%)$ & 99 \\
\hline Medium & $1(1.9 \%)$ & $0(0 \%)$ & 1 \\
\hline High & $4(7.8 \%)$ & $0(0 \%)$ & 4 \\
\hline
\end{tabular}

Table 7: Aerobic capacity ( $\mathrm{ml} / \mathrm{Kg} . \mathrm{min})$ in subjects

All values are mean \pm SD

\begin{tabular}{|c|c|c|c|c|}
\hline Sex & $\mathrm{n}$ & Mean & SD $( \pm)$ & Std. Error Mean \\
\hline Male & 51 & 37.44 & 3.90 & 0.54 \\
\hline Female & 53 & 41.63 & 3.14 & 0.43 \\
\hline
\end{tabular}

$\mathrm{P}<0.05$

Table 8: Number of subjects in different Grades of Aerobic capacity.

\begin{tabular}{|c|c|c|c|c|c|c|c|}
\hline \multirow{2}{*}{ Sex } & \multicolumn{7}{|c|}{ Table 8: Number of subjects in different Grades of Aerobic capacity. } \\
\cline { 2 - 7 } & Excellent & Very Good & Good & High Average & Low Average & Poor & Total \\
\hline & 0 & 26 & 22 & 3 & 0 & 0 & \\
\hline Male & $(0 \%)$ & $(50.9 \%)$ & $(43.1 \%)$ & $(5.8 \%)$ & $(0 \%)$ & $(0 \%)$ & 51 \\
\hline & 7 & 44 & 1 & 1 & 0 & 0 & \\
\hline Female & $(13.7 \%)$ & $(83.01 \%)$ & $(1.88 \%)$ & $(1.88 \%)$ & $(0 \%)$ & $(0 \%)$ & 53 \\
\hline Total & 7 & 70 & 23 & 4 & 0 & 0 & 104 \\
\hline
\end{tabular}

Table 9: Number of subjects in different grades of Sit -Ups test.

\begin{tabular}{|c|c|c|c|c|c|c|c|c|}
\hline \multirow[b]{2}{*}{ Sex } & \multicolumn{7}{|c|}{ Sit Ups grades (reps/min) } & \multirow[b]{2}{*}{ Tota } \\
\hline & Excellent & Good & $\begin{array}{c}\text { Above } \\
\text { Average }\end{array}$ & Average & $\begin{array}{c}\text { Below } \\
\text { Average }\end{array}$ & Poor & $\begin{array}{l}\text { Very } \\
\text { Poor }\end{array}$ & \\
\hline Male & $\begin{array}{c}0 \\
(0 \%) \\
\end{array}$ & $\begin{array}{c}0 \\
(0 \%)\end{array}$ & $\begin{array}{c}3 \\
(5.88 \%) \\
\end{array}$ & $\begin{array}{c}30 \\
(58.82 \%) \\
\end{array}$ & $\begin{array}{c}3 \\
(5.88 \%) \\
\end{array}$ & $\begin{array}{c}5 \\
(9.80 \%) \\
\end{array}$ & $\begin{array}{c}10 \\
(41.1 \%)\end{array}$ & 51 \\
\hline Female & $\begin{array}{l}0 \\
(0 \%)\end{array}$ & $\begin{array}{l}0 \\
(0 \%)\end{array}$ & $\begin{array}{c}1 \\
(1.88 \%)\end{array}$ & $\begin{array}{c}8 \\
(15.09 \%)\end{array}$ & $\begin{array}{c}8 \\
(15.09 \%)\end{array}$ & $\begin{array}{c}6 \\
(11.3 \%)\end{array}$ & $\begin{array}{c}30 \\
(56.6 \%)\end{array}$ & 53 \\
\hline Total & 0 & 0 & 4 & 38 & 11 & 11 & 40 & \\
\hline
\end{tabular}

Table 10: Number of subjects in different grade of Push -Up test.

\begin{tabular}{|c|c|c|c|c|c|c|c|c|}
\hline \multirow[b]{2}{*}{ Sex } & \multicolumn{7}{|c|}{ Push -up Grades (reps/min) } & \multirow[b]{2}{*}{ Total } \\
\hline & Excellent & Good & $\begin{array}{l}\text { Above } \\
\text { average }\end{array}$ & Average & $\begin{array}{l}\text { Below } \\
\text { average }\end{array}$ & Poor & $\begin{array}{l}\text { Very } \\
\text { poor }\end{array}$ & \\
\hline Male & $\begin{array}{ll}0 & (0 \%)\end{array}$ & $2(3.92 \%)$ & $8(15.68 \%)$ & $23(45.09 \%)$ & $7(13.72 \%)$ & $10(19.6 \%)$ & $1(1.96 \%)$ & 51 \\
\hline Female & $\begin{array}{c}0 \\
(0 \%)\end{array}$ & $\begin{array}{c}0 \\
(0 \%)\end{array}$ & $\begin{array}{c}1 \\
(1.88 \%)\end{array}$ & $\begin{array}{c}22 \\
(13.72 \%)\end{array}$ & $\begin{array}{c}23 \\
(43.3 \%)\end{array}$ & $\begin{array}{c}5 \\
(9.4 \%)\end{array}$ & $\begin{array}{c}2 \\
(3.77 \%)\end{array}$ & 53 \\
\hline Total & 0 & 2 & 9 & 45 & 30 & 15 & 3 & 104 \\
\hline
\end{tabular}

$\mathrm{P}<0.5$

Table 11: Number of subjects in different grades of Sit and Reach test.

\begin{tabular}{|c|c|c|c|c|c|c|c|c|}
\hline \multirow[t]{2}{*}{ Sex } & \multicolumn{7}{|c|}{ Sit and Reach Grades $(\mathrm{cm})$} & \multirow[t]{2}{*}{ Total } \\
\hline & Super & Excellent & Good & Average & Fair & Poor & Very poor & \\
\hline Male & $0 \quad(0 \%)$ & $1(1.96 \%)$ & $32(62.7 \%)$ & $17(33.33 \%)$ & $1(1.96 \%)$ & $0(0 \%)$ & $0 \quad(0 \%)$ & 51 \\
\hline Female & $\begin{array}{ll}0 & (0 \%) \\
\end{array}$ & $10(18.86 \%)$ & $37(69.81 \%)$ & $6(11.32 \%)$ & $0 \quad(0 \%)$ & $0 \quad(0 \%)$ & $\begin{array}{ll}0 & (0 \%)\end{array}$ & 53 \\
\hline Total & 0 & 11 & 69 & 23 & 1 & 0 & 0 & 104 \\
\hline
\end{tabular}


$\mathrm{p}<0.5$

\section{Result And Conclusion}

As per table no. 1 showing distribution of weight $(\mathrm{kg})$ in male and female subjects it was observed that mean \pm SD of male subjects was $70.5 \pm 13.56$ and female subjects was $55.03 \pm 8.18$. Distribution of height $(\mathrm{cm})$ in subjects was observed and it was found that mean \pm SD of male subjects was $106 \pm 9.95$ and female subjects was $152 \pm 16.2$ (table 2 ) with $p<0.5$. The mean \pm SD of BMI of male subjects was $25.15 \pm 5.34$ and female subjects was $22.15 \pm 4.13$ (table 3 ). In present study $54.9 \%$ male subjects and $73.6 \%$ of female subjects were in normal BMI $\left(\mathrm{kg} / \mathrm{m}^{2}, 21.6 \%\right.$ male subjects and $9.4 \%$ female subjects was obese, $19.6 \%$ male subjects and $9.4 \%$ female subjects were overweight and about $3.9 \%$ male subjects and $7.5 \%$ female subjects were underweight (table 4). The mean \pm SD of waist to hip ratio in male and female subjects was $0.82 \pm 0.10$ and that of female subjects was $0.75 \pm$ 0.05 . Here $90.1 \%$ of male subjects were at low risk, $1.9 \%$ at moderate risk and $7.8 \%$ were in high risk group of waist to hip ratio but $100 \%$ female subjects were at low risk (table 5).

The mean \pm SD of aerobic capacity in male subjects were $37.44 \pm 3.90$ and or female subjects were $41.63 \pm 3.14 .83 .01 \%$ female subjects were in very good grade and $13.7 \%$ female subjects were in excellent grade of aerobic capacity (ml/kg.min) as compared to male subjects who have poor aerobic capacity (table 7).

The sit up test grade (reps/min), 5.88\% male subjects and $1.88 \%$ female subjects were in above average grade, $58.82 \%$ male subjects and $15.09 \%$ of female subjects were in average grade, $5.88 \%$ male subjects and $15.09 \%$ female subjects were below average, $9.80 \%$ male subjects and $11.3 \%$ female subjects were in poor grades (table 9).The push up test (reps/min), 3.92\% male subjects were in good grade, $15.68 \%$ male subjects and $1.88 \%$ female subjects were above average, $45.09 \%$ male subjects and $41.5 \%$ female subjects were in average grade, $13.72 \%$ male subjects and $43.3 \%$ female subjects were below average and $19.60 \%$ male subjects and $9.4 \%$ female subjects were in poor grade and $9.6 \%$ male subjects and $3.77 \%$ female subjects were in very poor grade (table 10)The sit and reach (flexibility) test in $\mathrm{cm}$, about $62.7 \%$ male subjects and $69.81 \%$ female subjects were in good grade, $33.33 \%$ male subjects and $11.32 \%$ female subjects were average and $1.96 \%$ male subjects and $18.86 \%$ female subjects were excellent and $1.96 \%$ male subjects were in fair grade (table 11 ).

\section{Discussion}

Physical fitness is an important marker in youth (20). The result of present study showed the prevalence of physical fitness according to BMI. It was reported that more percentage of obesity and overweight in male subjects as compared to females $(21,22)$. These findings are in support with the present study. In this study maximum numbers of male and female subjects were in low risk of waist to hip ratio. Majority of rural female subjects belong to a very good grade of aerobic capacity (23), similarly it was observed that aerobic capacity was higher in female subjects as compared to male subjects. $\mathrm{VO}_{2}$ max levels were found decreased significantly in obese group $(24,25)$. In present study it was found that percentage of overweight and obesity was higher in male subjects than female and this is the reason for low aerobic capacity in males. But our results contradict with the findings which showed that Iranian male students were significantly taller, heavier and had higher $\mathrm{VO}_{2}$ max level than female students. Our result correlate with the findings that majority of female student belong to poor physical fitness condition $(20,26,21,23)$ these results support our study. The result is affected because of physical life style and physical activity levels of subjects. Further the performance of subjects is affected due to different physical characteristics. The research has provided early information to help the students to understand their performance level or their physical fitness.

\section{Bibliography}

[1]. SAHA PN: Work physiology, Paper presented in Advanced Training Courses in Ergonomics, at SNDT women's University, Mumbai, 22-27 February (1996).

[2]. Casperson, Powell \& Christenson. Public Health Report, 1985 Mar-Apr: 100 (2).

[3]. FB Ortega, JR Ruiz, MJ Castillo and M Sjo "stro"m Metter. International journal of obesity 2008; 32 1-11.

[4]. Blair SN, Kohl III HW, Paffenbarger Jr RS, Claek DG, Cooper KH, Gibson LW. JAMA 1989; 262:2395-2401.

[5]. Metter EJ, Talbot LA, Schrager M, Conwit R. J. Gerontol A Biol Sci Med Sci 2002; 57: B3 59-365.

[6]. Kopelman P. Obesity as a medical problem. Nature. 2000; 404:631-634

[7]. Manson JE, Skerrett PJ, Greenland P, Vantallie TB. Arch Intern Med. 2004; 164:249-258

[8]. Mosco L, Appel LJ, Benjamin EJ, et al. Circulation. 2004; 109: 672-693.

[9]. Francischetti EA, Genelhu VA. Int J Clin Prac 2007; 61 (2): 269-280.

[10]. Despres JP, Lemieux I. Nature 2006; 444 (7121): 881-7.

[11]. Hu G, Lindstrom J, Valle TT, et al. Arch Intern Med 2004; 164 (8): 892-6.

[12]. Kurukulasuriya LR, Govindrajan G, Sowers J. Expert Rev Cardiovasc Ther 2006; 4 (4): 487-502.

[13]. Puhl R, Brownell KD. Obes Res 2001; 9 (12): 788-805.

[14]. Yajnic CS. Obesity epidemic in India: intrauterine origins? The proceedings of the nutrition society. 2004; 63: 387-396.

[15]. WHO. Physical status: The use and interpretation of anthropometry. Report of a WHO expert committee. WHO technical report series 854. Geneva: World Health Organisation, 1995.

[16]. WHO. Obesity: Preventing and managing the global epidemic. Report of a WHO consultation. WHO Technical Report Series 894. Geneva: World Health Organisation, 2000.

[17]. WHO expert consultation. Appropriate body mass index for Asian populations and its implication for policy and intervention strategies. The Lancet, 2004; 157-163.

[18]. Golding et al. (1986). The Y's way to physical fitness ( $3^{\text {rd }}$ ed)

[19]. Wells KF \& Dillon EK (1952). The Sit and Reach. A test of back and leg flexibility. Research Quarterly, 23. 115-118.

[20]. FB Ortega et al; Physical fitness level among European adolescents: The HELENA study: Br J Sports Med 2011; 45: 20-29.

[21]. Kwok-kei Mak, Wing-Sze Lo, G Neil Thomas, Alison M McManus, Jefferey R Day and Tai-Hing Lam. Health related physical fitness and weight status in Hong Kong adolescents: BMC Public Health 2010; 10:88.

[22]. Morteza Jourkesh, Iraj Sadri, Ali Ojagi and Sharanvard Amineh. Determination of fitness level in male and female college aged students. Archives of Applied Science Research 2011; 3 (2): 326-333.

[23]. Suna Hasalkar, S. Rajeshwari and B. Nutan. Measures physical fitness levels of the college going aged students. Anthropologist 2005; 7 (3): 185-187.

[24]. Masomeh K, Morteza J, Bita MK. Comparison of physical fitness level among normal weight and obese female university students. Annals of Biological Research 2011; 2 (3): 126-133

[25]. Wi- Young SO \& Dai- Hyuk Choi. Difference in physical fitness and cardiovascular function depend on BMI in Korean men. Journal of Sport Science and Medicine 2010; 9: 239-244.

[26]. Jensen \& Fisher. Determination of fitness level in male and female college aged students. Archives of Applied Science Research 2011; 3 (2): $326-333$. 